\title{
IMPLEMENTASI KONSEP THUMA'NINAH SEBAGAI UPAYA MENGELOLA KECEMASAN PADA PANDEMI COVID-19 (ANALISIS PEMIKIRAN IBNU QAYYIM AL-JAUZIYAH)
}

\author{
Oleh: \\ Arrasyid " \\ Universitas Islam Negeri Imam Bonjol Padang \\ arrasyid350@gmail.com
}

\begin{abstract}
This study aims to explain and analyze the concept of thuma'ninah Ibnu Qayyim al-Jauziyah as an effort to manage the anxiety that occurs in the Covid-19 pandemic. This research is qualitative research with a character study approach and uses exploratory, interpretation, and analysis methods. This study found data that the implementation of the thuma'ninah concept of Ibnu Qayyim al-Jauziyah as an effort to manage the anxiety that occurred during the Covid-19 pandemic, namely; first, implementing his understanding of the book of Allah Allah. Second, implementing the asthma of Allah regarding asySyukur. Third, implementing an understanding of the test is a form of Allah's love for His servants. By implementing these 3 (three) understandings, the anxiety felt by humans in the Covid-19 pandemic will be managed properly.
\end{abstract}

Keywords: Ibnu Qayyim al-Jauziyah, Pandemic Covid-19, Thuma'ninah.

\section{A. Pendahuluan}

Coronavirus disease 2019 (Covid 19) merebak pada awal tahun 2020 dan mengakibatkan gemparnya dunia. Wuhan, Tiongkok disinyalir sebagai asal usul virus ini, yang ditemukan pada akhir Desember tahun 2019 (Yuliana, 2020: 187) World Health Organization (WHO) atau Organisasi Kesehatan Dunia pada 12 Maret 2020 mengumumkan Covid 19 sebagai pandemi (Susilo, 2020: 45) Hingga saat ini menjelang pertengahan bulan
April 2021, 133 juta kasus ditemukan; adapun yang sembuh sebanyak 75,4 juta; sementara yang meninggal dunia telah 2,89 juta (en.wikipedia.org). Di indonesia sendiri semenjak diumukannya kasus positif Covid 19 pertama dan kedua pada tanggal 2 Maret 2020 (Burhan, 2020: 3) hingga saat ini setelah setahun lebih berlalu, terdapat 1,55 juta kasus, yang sembuh sebanyak 1,39 juta, sementara yang meninggal dunia 42.064 orang (covid19.go.id). 
Covid 19 dengan segala dampak yang terjadi, telah mengubah situasi dan kondisi dunia. Banyak kegiatan yang biasa dilakukan manusia menjadi tidak bisa dilakukan, karena ada protokol kesehatan yang harus diterapkan. Terdapat peraturan pemerintah yang harus dijalani demi kebaikan bersama, kesehatan dan keselamatan semuanya. Namun, di balik hal penting - tentang kesehatan yang harus dijaga manusia pada masa pandemi Covid 19, terdapat hal lain yang harus diperjuangkan pula. Kehidupan yang harus dijalani manusia seperti biasa adanya untuk memenuhi kebutuhan hidup.

Situasi-situasi yang mendilemakan demikian, yang terjadi selama pandemi Covid 19 telah melahirkan kecemasan di tengah masyarakat. Dalam keadaan seperti itu, manusia perlu mengelola rasa cemas agar tidak berlebihan-dalam batas sewajarnya - menjadikannya sebagai sebuah sikap mawas diri atau waspada. Memutar balikkan perasaan perlu dilakukan manusia. Mengubah kecemasan menjadi ketenraman. Fakta bahwa Virus Corona masih menyebar masif saat ini harus dihadapi manusia dengan tenang dan tentram, bahasa agamanya thuma'ninah. Manusia tidak boleh cemas berkepanjangan. Manusia perlu menentramkan jiwanya.

Dalam dunia Islam di antara tokoh yang memiliki pemikiran tentang thuma'ninah adalah Ibnu Qayyim al-Jauziyah. Ibnu Qayyim alJauziyah adalah ulamawan Muslim yang cukup produktif dalam menuliskan pemikiran-pemikirannya. Mengetahui bagaimana konsep thuma'ninah ala Ibnu Qayyim alJauziyah bekerja dalam menenangkan kecemasan yang dialami manusia dirasa penting untuk membumikannya.

Berdasarkan penelusuran penulis, ada beberapa penelitian yang terkait dengan material penelitian ini; Ibnu Qayyim al-Jauziyah dan Covid 19, di antaranya, yaitu; pertama, penelitian yang ditulis oleh Makmudi, dkk. tahun 2018 yang berjudul Pendidikan Jiwa Perspektif Ibn Qayyim al-Jauziyah dengan fokus penelitian mengkaji dan menganlisis pemikiran Ibnu Qayyim al-Jauziyah tentang pendidikan jiwa (Makmudi, 2018: 42). Kedua, penelitian yang berjudul Metode Penafsiran Ibnu Qayyim al-Jauziyah yang ditulis oleh Hafizzullah tahun 2018 yang fokus meneliti metode penafsiran yang digunakan oleh Ibnu Qayyim alJauziyah (Hafizzullah, 2018: 67). Ketiga, penelitian yang ditulis tahun 2017 oleh Rizal Darwis yang berjudul Pemikiran Ibnu Qayyim alJauziyah terhadap Paradigma Perubahan Hukum dengan fokus penelitian mengeksplorasi pemikiran Ibnu Qayyim al-Jauziyah tentang perubahan hukum (Darwis, 2017: 67)

Keempat, penelitian yang dilakukan oleh Eman Supriatna tahun 2020 yang berjudul Wabah Corona Virus Disease Covid 19 dalam Pandangan Islam, dengan fokus mengkaji apakah wabah Covid 19 sama dengan wabah tho'un yang terjadi pada masa Nabi Muhammad SAW (Supriatna, 2020: 556)

Kelima, penelitian yang berjudul Konsep Tafakkur dalam al- 
Quran dalam Menyikapi Coronavirus (Covid 19) yang ditulis oleh Indriya tahun 2020 yang fokus meneliti tentang pentingnya tafakkur seperti yang diajarkan dalam al-Quran pada masa terjadinya pandemi Covid 19 (Indriya, 2020: 211)

Keenam, penelitian yang berjudul Virus Corona dalam Perspektif Sunnah yang ditulis oleh Firdaus tahun 2020, yang fokus meneliti tentang istilah virus di dalam hadis Nabi SAW. dan cara Nabi SAW. mengatasinya (Firdaus, 2020: 13).

Semakin tingginya kasus penyebaran virus corona, semakin tinggi pula kecemasan yang dihadapi masyarakat. Oleh sebab itu, artikel ini akan membahas bagaimana implementasi konsep thuma'ninah perspektif Ibnu Qayyim al-Jauziyah sebagai upaya mengelola kecemasan pada pandemi Covid 19.

\section{B. Metode Penelitian}

Penelitian ini adalah penelitian kualitatif dengan pendekatan studi tokoh. Dalam hal ini, mengkaji pemikiran Ibnu Qayyim al-Jauziyah tentang thuma'ninah yang dianalisis sebagai upaya mengatasi kecemasan yang terjadi pada masa pandemi Covid 19. Metode yang digunakan ada 3 (tiga). Pertama, eksploratif, yaitu; mengeksplorasi dan menjabarkan data yang ada secara apa adanya. Kedua, interpretasi, yaitu; menyelami karya tokoh untuk menemukan makna dan nuansa yang dimaksud tokoh secara khas (Bakker dan Zubair, 1990: 63). Ketiga, analisis, yaitu; "jalan yang dipakai untuk mendapatkan ilmu pengetahuan ilmiah dengan mengadakan pemerincian terhadap obyek yang diteliti, atau cara penanganan terhadap suatu obyek ilmiah tertentu dengan jalan memilah-milah antara pengertian yang satu dengan pengertianpengertian yang lain, untuk sekedar memperoleh kejelasan mengenai halnya" (Sudarto, 2002: 59)

Sumber penelitian ini ada 2 (dua); primer dan sekunder. Sumber primernya adalah karya Ibnu Qayyim al-Jauziyah yang berjudul Madarij alSalikin Baina Manazil Iyyaka Na'bud wa Iyyaka Nasta'in - karya tersebut adalah sumber utama atau rujukan utama dari penelitian ini. Sementara sumber sekundernya adalah karyakarya lain yang membahas mengenai pemikiran Ibnu Qayyim al-Jauziyah. Adapun alasan mengapa konsep thuma'ninah yang menjadi fokus penelitian, karena lawan dari kecemasan adalah ketenangan, sehingga memahami konsep thuma'ninah dapat menjadi penyeimbang yang dirasakan manusia pada masa pandemi Covid 19 sekarang. Sementara pemilihan tokoh Ibnu Qayyim al-Jauziyah sendiri dikarenakan gaya bahasa dan tutur kata karyanya nan elok dan menyentuh jiwa. Sebagaimna yang diungkapkan oleh Abdul Kadir Riyadi bahwa "Ibnu Qayyim alJauziyah memiliki kelebihan di atas rata-rata dalam memilih kata yang indah dan lembut. Walau harus menulis dalam ribuan lembar, beliau tidak pernah kehabisan kata-kata untuk melukiskan maksud dan tujuannya" (Riyadi, 2016: 289) 


\section{Hasil dan Pembahasan}

\section{Riwayat Hidup dan Karya Ibnu Qayyim al-Jauziyah}

Ibnu Qayyim al-Jauziyah bernama lengkap Muḥammad bin Abī Bakr bin Ayyub bin Sa'ad bin Hariz bin Makiy Zaiduddīn al-Zur'i alDimasyqi al-Hanbali (Hafizzullah, 2018: 68). Beliau lahir pada tanggal 7 Shafar $691 \mathrm{H} / 4$ Februari $1292 \mathrm{M}$ di desa Hauran, sekitar 55 Mil sebelah tenggara Kota Damaskus, Suriah (Ni'mah, 2018: 196) Beliau berasal dari keluarga yang religius, berilmu pengetahuan, terpandang dan memadai secara ekonomis. Ayah beliau yang bernama Abu Bakr ibn Ayyub al-Zur'i adalah seorang pimpinan dan tonggak (qayyum) pada madrasah yang bernama al-Jauziyah, yang kemudian menjadi julukan populer untuk Ibnu Qayyim alJauziyah (Islami dan Rosyad, 2020: 36-37)

Semenjak kanak-kanak Ibnu Qayyim al-Jauziyah (selanjutnya akan disebut Ibnu Qayyim) tersohor sebagai anak yang penurut dan gemar belajar. Meski usianya masih relatif muda, ia sudah begitu rajin melalukan berbagai ibadah dan zikir. Tidak seperti kebanyakan temantemannya pada umumnya yang senang bermain. Ibnu Qayyim lebih banyak menghabiskan detik demi detik waktu untuk membaca, beribadah dan hebatnya lebih memilih duduk bersama orang-orang dewasa pada majlis pengajian (Riyadi, 2016: 272) Tidak salah beliau menjadi ulama besar yang dikenang hingga sekarang, berkat kehidupannya yang telah tertata semenjak usia kanak-kanak.

Mengenai riwayat keilmuan yang didapatkannya, Ibnu Qayyim alJauziyah belajar kepada banyak ulama sehingga ia mendapatkan berbagai bidang keilmuan Islam. Di antara gurunya, yaitu; Abu Bakr ibn Ayyub al-Zur'i, ayahnya yang mengajarkannya Ilmu Waris; Imam al-Harran Ismail bin Muhammad alFarra' mengajarkannya Ilmu Fara'idh; Abdul Fath al-Ba'balaki dan al-Shaffi al-Hindi mengajarkannya Ilmu Fiqh; Syaik Jamaluddin al-Mizzi mengajarkannya Ilmu Tafsir; dan Ibnu Taimiyah, yang kemudian menjadi guru yang paling berpengaruh atasnya (Na'mah, 2015: 67), karena dapat mempertajam berbagai keilmuan darinya, seperti; Tafsir, Fiqh, Hadis, Fara'idh, Ilmu Ushul dan Ilmu Kalam (Maula, 2019: 18-19)

Keunggulan dan keistimewaan yang dimiliki oleh Ibnu Qayyim telah menuliskan tanda-tandanya sebagai salah satu figur ulama sufi yang disegani dan ditakzimkan. Ketika wafat pada tahun $751 \mathrm{H} / 1353 \mathrm{M}$, beliau telah mewariskan legasi intelektual yang layak dipelihara dan dikembangkan untuk kemajuan ilmu pengetahuan dan nilai-nilai moral agama (.Riyadi, 2016: 290) Di antara warisan intelektualnya, yaitu; Miftar Dar al-Sa'adah wa Mansyur Wilayah AM al-'Urn wa al-Iradah, al-Ijtihad wa al-Taqlid, Ijtima' al-Juyusy alIslamiyah, al-A'lam bi Ittisa 'I Thuruq al-Ahkam, Ushul al-Tafsir, al-Amali al-Makkiyah, Amtsal alQuran, al-Ijaz, Madarij al-Salikin, dan lain-lain. 


\section{Kecemasan pada Masa Pandemi Covid 19}

Informasi tentang jumlah korban yang terpapar Virus Corona kian hari Ibnu Qayyim al-Jauziyah bernama lengkap Muḥammad bin Ab̄̄ Bakr bin Ayyub bin Sa'ad bin Hariz bin Makiy Zaiduddīn al-Zur'i alDimasyqi al-Hanbali (Hafizzullah, 2018: 68) Beliau lahir pada tanggal 7 Shafar 691 H / 4 Februari 1292 M di desa Hauran, sekitar 55 Mil sebelah tenggara Kota Damaskus, Suriah (Ni'mah, 2018: 196) Beliau berasal dari keluarga yang religius, berilmu pengetahuan, terpandang dan memadai secara ekonomis. Ayah beliau yang bernama Abu Bakr ibn Ayyub al-Zur'i adalah seorang pimpinan dan tonggak (qayyum) pada madrasah yang bernama al-Jauziyah, yang kemudian menjadi julukan populer untuk Ibnu Qayyim alJauziyah (Islami dan Rosyad, 2020: 36-37)

Semenjak kanak-kanak Ibnu Qayyim al-Jauziyah (selanjutnya akan disebut Ibnu Qayyim) tersohor sebagai anak yang penurut dan gemar belajar. Meski usianya masih relatif muda, ia sudah begitu rajin melalukan berbagai ibadah dan zikir. Tidak seperti kebanyakan temantemannya pada umumnya yang senang bermain. Ibnu Qayyim lebih banyak menghabiskan detik demi detik waktu untuk membaca, beribadah dan hebatnya lebih memilih duduk bersama orang-orang dewasa pada majlis pengajian (Riyadi, 2016: 272) Tidak salah beliau menjadi ulama besar yang dikenang hingga sekarang, berkat kehidupannya yang telah tertata semenjak usia kanak-kanak.

Mengenai riwayat keilmuan yang didapatkannya, Ibnu Qayyim alJauziyah belajar kepada banyak ulama sehingga ia mendapatkan berbagai bidang keilmuan Islam. Di antara gurunya, yaitu; Abu Bakr ibn Ayyub al-Zur'i, ayahnya yang mengajarkannya Ilmu Waris; Imam al-Harran Ismail bin Muhammad alFarra' mengajarkannya Ilmu Fara'idh; Abdul Fath al-Ba'balaki dan al-Shaffi al-Hindi mengajarkannya Ilmu Fiqh; Syaik Jamaluddin al-Mizzi mengajarkannya Ilmu Tafsir; dan Ibnu Taimiyah, yang kemudian menjadi guru yang paling berpengaruh atasnya (Na'mah, 2015: 67) karena dapat mempertajam berbagai keilmuan darinya, seperti; Tafsir, Fiqh, Hadis, Fara'idh, Ilmu Ushul dan Ilmu Kalam (Maula, 2019: 18-19).

Keunggulan dan keistimewaan yang dimiliki oleh Ibnu Qayyim telah menuliskan tanda-tandanya sebagai salah satu figur ulama sufi yang disegani dan ditakzimkan. Ketika wafat pada tahun $751 \mathrm{H} / 1353 \mathrm{M}$, beliau telah mewariskan legasi intelektual yang layak dipelihara dan dikembangkan untuk kemajuan ilmu pengetahuan dan nilai-nilai moral agama (.Riyadi, 2016: 290) Di antara warisan intelektualnya, yaitu; Miftar Dar al-Sa'adah wa Mansyur Wilayah AM al-'Urn wa al-Iradah, al-Ijtihad wa al-Taqlid, Ijtima' al-Juyusy alIslamiyah, al-A'lam bi Ittisa 'I Thuruq al-Ahkam, Ushul al-Tafsir, al-Amali al-Makkiyah, Amtsal alQuran, al-Ijaz, Madarij al-Salikin, dan lain-lain.. 


\section{Konsep Thuma'ninah Perspektif Ibnu Qayyim al- Jauziyah}

Ada istilah sakinah ada pula thuma'ninah.

Sebelum

mengeksplorasi mendalam tentang thuma'ninah itu seperti apa. Satukan frame dulu bedanya sakinah dan thuma'ninah itu seperti apa. 2 (dua) kata ini maknanya berbeda tapi saling terkait. Bagi Ibnu Qayyim, jika sakinah di artikan dengan ketenangan maka thuma'ninah adalah ketentraman. Sakinah itu adalah keadaan di mana secara tiba-tiba hilangnya rasa takut. Sementara thuma'ninah adalah pengaruh yang dirasakan karena adanya sakinah (alJauziyah, 1980: 414) Artinya sakinah dulu baru thuma'ninah. Maka, thuma'ninah lebih mendalam ketentraman yang dirasakan disbanding sakinah. Namun, keduaduanya adalah wujud pemberian / anugerah Tuhan, istilah tasawufnya ahwal bukan maqamat sesuatu yang bisa diusahakan. Sehingga seakaanakan kata Ibnu Qayyim thuma'ninah merupakan puncak dari sakinah (alJauziyah, 1980: 414)

Lebih lanjut, beda antara sakinah dengan thuma'ninah dalam pandangan Ibnu Qayyim dapat dilihat dari perumpamaan berikut; keadaan sakinah itu bagaikan seseorang yang berhadapan dengan musuh, dan ketika musuh lari darinya kemudian hatinya menjadi tenang. Sementara keadaan thuma'ninah itu bagaikan seseorang yang berhadapan dengan musuh pula, dan ketika itu pintu benteng terbuka, lalu ia masuk ke dalamnya sehingga ia merasakan aman seaman-amannya (al-Jauziyah,
1980: 414) Di sini tampak jelas bahwa keadaan yang dirasakan saat thuma'ninah lebih mendalam dibanding sakinah. Adalah bahwa saat musuh lari meninggalkan seseorang itu kemungkinan ia kembali dan menghadang seseorang itu bukan hal yang mustahil. Sementara keadaan thuma'ninah saat seseorang itu berada dalam benteng membuat ia merasakan ketentraman karena musuh tidak bisa menghadangnya.

Dalam karyanya yang berjudul Madarij al-Salikin Baina Manazil Iyyaka Na'bud wa Iyyaka Nasta'in sub bab tentang thuma'ninah Ibnu Qayyim memulai narasi tentang konsep thuma'ninah dengan menuliskan firman Allah SWT. Q.S. ar-Ra'd [13]: 28 dan al-Fajr [89]: 2730

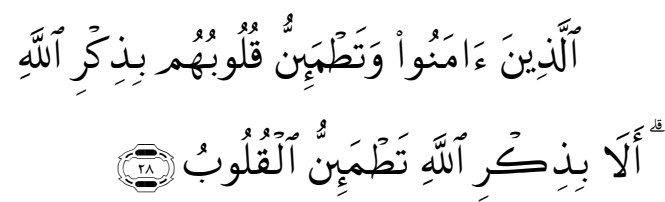

Artinya: "(yaitu) orang-orang yang beriman dan hati mereka manjadi tenteram dengan mengingat Allah. Ingatlah, hanya dengan mengingati Allah-lah hati menjadi tenteram".

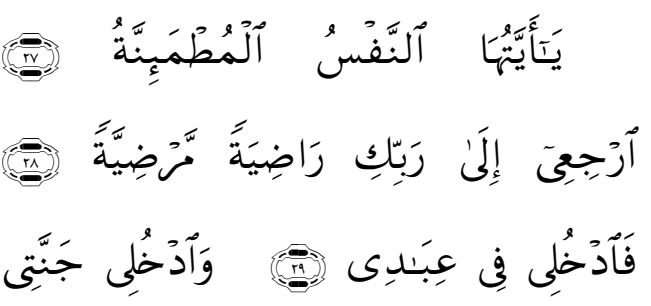


Artinya: "Hai jiwa yang tenang. Kembalilah kepada Tuhanmu dengan hati yang puas lagi diridhai-Nya. Maka masuklah ke dalam jama'ah hamba-hamba-Ku, Masuklah ke dalam syurga-Ku".

Ibnu Qayyim menafsirkan ayat tersebut bahwa Allah membuat di dalam hati orang-orang yang beriman dan di dalam jiwanya thuma'ninah. Kemudian Allah memberikan kabar gembira bahwa orang-orang yang memiliki jiwa yang thuma'ninah akan masuk surga. Firman Allah, "hai jiwa yang tentram, kembalilah kepada Rabbmu", menjelaskan tentang jiwa manusia tidak akan kembali kepada Allah kecuali jiwa tersebut dalam keadaan thuma'ninah (al-Jauziyah, 1980: 414)

Secara etimologi thuma'ninah berasal dari kata طَ (thamana) artinya tetap, hilang takut dan tenang (Muslim, 2019: 32). Ibnu Qayyim mendefenisikan thuma'ninah dimaknai sebagai ketentraman hati terhadap sesuatu, tidak cemas dan gelisah (al-Jauziyah, 1980: 414) Artinya keadaan thuma'ninah itu adalah merasa amannya hati, tidak ada yang dicemaskan atau digelisahkan. Perasaan reda dan lega setelah melewati situasi yang dilalui. Percaya dan yakin bahwa semuanya akan baik-baik saja. Tidak ada yang ditakutkan lagi.

Terkait derajat thuma'ninah Ibnu Qayyim membaginya menjadi 3 (tiga) derajat, yaitu; pertama, thuma'ninah hati karena menyebut asma Allah (al-Jauziyah, 1980: 415) Maksudnya thuma'ninah yang muncul karena menyebut asma Allah dan membaca kitab-Nya, yang terbagi ke dalam beberapa hal; (1) thuma'ninah dari rasa takut kepada harapan. Ibnu Qayyim contohkan dengan seseorang yang telah lama dihinggapi rasa takut, lalu Allah turunkan thuma'ninah kepadanya, sehingga hatinya menjadi tentram dan penuh harapan. (2) thuma'ninah dari kegelisahan kepada hukum (alJauziyah, 1980: 415). Maksudnya orang-orang yang gelisah karena harus menanggung berbagai macam kewajiban dan beban perintah sehingga hatinya menjadi gelisah dan kesabarannya melemah. Namun, karena pasrah akan hukum agama dan hukum alam, Allah berikan thuma'ninah kepadanya. (3) thuma'ninah dari cobaan kepada pahala (al-Jauziyah, 1980: 415) Maksudnya thuma'ninah yang didapatkan karena seseorang meyakini jika cobaan yang terjadi padanya ada pahala di baliknya. Maka, hatinya akan menjadi tentram seketika.

Kedua, thuma'ninah ruh karena 3 (tiga) hal; (1) saat mencapai tujuan pengungkapan hakikat (alJauziyah, 1980: 415) Maksud Ibnu Qayyim tentang tujuan pengungkapkan hakikat di sini adalah mengungkapkan hakikat iman dan syariat Islam. Artinya bahwa kehadiran manusia ke muka bumi ini tujuan pengungkapan hakikat yang hendak diraih adalah hakikat iman dan syariat Islam. Karena mencari pengungkapan hakikat tersebut hati manusia thuma'ninah karenanya. Dalam artian pencapaian untuk meraih tujuan tersebut melaharikan thuma'ninah dalah hidup manusia. 
Selain itu, bagi Ibnu Qayyim pengungkapan hakikat juga tentang memahami asma' dan sifat Allah. Dalam hemat penulis, bahwa adalah merupakan tujuan penciptaan manusia di muka bumi ini mengenal Penciptanya, bagaimana asma' dan sifatnya. Pemahaman tentang tersebut akan menjadikan manusia tidak sekedar ada di dunia tapi juga memiliki makna. Hal demikian, akan melahirkan thuma'ninah dalam hidup manusia.

(2) saat merindukan janji (alJauziyah, 1980: 416) maksudnya ruh menjadi thuma'ninah karena merindukan apa yang telah dijanjikan kepadanya. Adalah bahwa manusia yang berbuat baik ada kenikmatan yang akan didapatkannya. Sementara manusia yang berbuat buruk ada kesengsaraan yang akan didapatkannya - kecuali jika ia bertaubat. Maka, ruh yang senantiasa berada pada jalur kebaikan, kerinduan akan janji-janji Tuhan tentang balasan yang akan didapatkan, senantiasa melahirkan thuma'ninah di dalam dirinya.

(3) saat berpisah dan untuk berkumpul kembali (al-Jauziyah, 1980: 416) Bahwa ruh manusia berasal dari Tuhan dan akan kembali kepada Tuhan. Saat terjadinya perpisahan dan penantian untuk berkumpul kembali melahirkan thuma'ninah dalam diri manusia. Adalah bahwa kehidupan akhirat jauh lebih baik daripada kehidupan dunia. Maka, senantiasa menanti kembalinya ruh kepada Tuhan dengan menjalani kehidupan dunia ini dengan baik akan melahirkan thuma'ninah dalam kehidupan manusia.

Ketiga, thuma'ninah karena 3 (tiga) hal; (1) Menyaksikan kasih sayang Allah (al-Jauziyah, 1980: 416) Maknanya thuma'ninah itu muncul setelah merasakan bagaimana kasih sayang Allah kepada dirinya. Dalam arti tersaksikannya segala hal dalam hidup ini merupakan bentuk kasih sayang Allah. (2) Kebersamaan menuju kekekalan (al-Jauziyah, 1980: 416) Penghambaan manusia kepada Allah adalah cara manusia untuk mendapatkan kebersamaan lalu kekekalan hidup di akhirat bersama Allah, yang kemudian melahirkan thuma'ninah di dalam dirinya. (3) Kedudukan menuju cahaya azali. Ibnu Qayyim menjelaskannya sebagai pengetahuan tentang ketetapan azali Tuhan yang tidak akan berubah dan berganti. Karena mengetahui ketetapan azali tersebut hati menjadi thuma'ninah (alJauziyah, 1980: 416)

\section{Implementasi Konsep Thuma'ninah Perspektif Ibnu Qayyim al-Jauziyah sebagai Upaya Mengelola Kecemasan pada Pandemi Covid 19}

Adalah terdapat 3 (tiga) hal yang bisa diimplementasikan dari konsep thuma'ninah perspektif Ibnu Qayyim, sehingga dapat membuat manusia mengelola kecemasan yang dihadapi pada masa pandemi Covid 19 ini.

Pertama, mengimplementasikan pemahaman tentang kitab Allah Allah. Dalam hal ini, ayat al-Quran 
yang berkaitan dengan kesabaran. Allah berfirman;

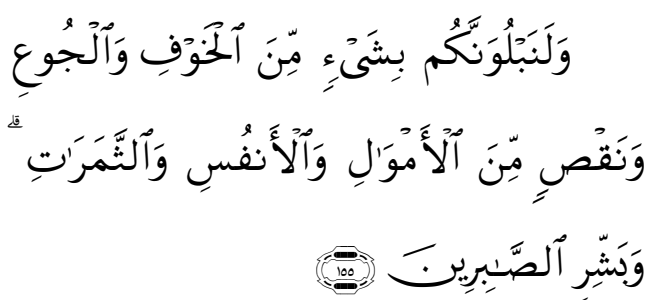

Artinya: "Dan sungguh akan Kami berikan cobaan kepadamu, dengan sedikit ketakutan, kelaparan, kekurangan harta, jiwa dan buahbuahan. dan berikanlah berita gembira kepada orang-orang yang sabar". (Q.S. al-Baqarah [2]: 155) (Departemen Agama RI, 2017: 24)

Dari ayat di atas dapat dipahami bahwa ujian yang diberikan oleh Tuhan hanyalah dalam kadar yang sedikit; sedikit ketakutan, kelaparan, kekurangan harta, jiwa dan buahbuahan. Dalam keadaan demikian, Tuhan ingin hamba-Nya agar sabar sebentar saja, karena terdapat berita gembira setelahnya. Kondisi manusia saat ini, dengan adanya pandemi Covid 19 dengan segala kecemasankecemasan yang terjadi adalah cukup disabari. Sabar dalam artian tabah dalam menghadapi berbagai ujian yang diberikan Allah, baik itu ujian kenikmatan maupun musibah (Putri, 2019: 82). Dengan bersabar pada masa pandemi Covid-19 ini menjadikan seseorang menahan diri untuk tidak berkeluh kesah dan menerima apa yang terjadi. Namun, terus berusaha menjalani kehidupan ini semaksimal dan sebaik mungkin.

Kedua, mengimplementasikan asma Allah (al-Jauziyah, 1980: 415)
Pengimplementasiaan asma Allah dapat dilakukan dengan memahami makna-makna asma Allah. Dalam hal ini asma Allah tentang asy-Syukur (Maha Menerima Syukur)misalnya. Syukur dapat dimaknai sebagai pengakuan terhadap nikmat yang dikaruniakan Allah yang disertai dengan kedudukan kepadaNya dan mempergunakan nikmat tersebut sesuai dengan tuntunan dan kehendak Allah (Mahfud, 2014: 380) Dalam hal ini, situasi yang terjadi karena pandemi Covid-19. Hal yang dapat dilakukan manusia untuk menenangkan hati dan pikirannya adalah dengan menerima segala yang terjadi dan mensyukurinya. Mengingat-ingat lagi, nikmat hidup yang terus diterima sepanjang hidup ini. Bahwa dengan adanya ujian yang terjadi karena situasi pandemi Covid19, di balik hal itu kebahagiaan apa yang tengah dipersiapkan Allah untuk hamba-Nya.

Ketiga, mengimplementasikan pemahaman tentang ujian adalah bentuk kasih sayang Allah kepada hamba-Nya (al-Jauziyah, 1980: 416) Tidak mungkin seorang Pemilik memperlakukan milik-Nya yang melahirkan ketidaksenangan atas milik-Nya. Justru sebaliknya, bahwa Pemilik lebih tahu jalan mana yang akan menjadikan milik-Nya mendapatkan ketenangan atau kebahagiaan dalam hidup sehingga ia datangkan ujian sebagai bentuk kasih sayang-Nya. Sebagaimana istilah Ibnu Qayyim "ujian-ujian itu mengandung nilai kemuliaan, bentuknya memang musibah dan cobaan, tetapi di baliknya tersimpang rahmat dan nikmat" (al-Jauziyah, 2000: 50) Bahagia terasa nikmat 
karena ada kesedihan terlebih dulu. Jalaluddin Rumi bersyair:

"Jika awan tak menangis,

Akankah taman mekar?

Jika bayi tak menangis,

Akankah susu ngalir?

Sang Perawat hanya beri susu kala keras tangismu?" (Bagir, 2015: 86)

Di dalam menghadapi kesedihan atau ujian, sebelum Allah datangkan bahagia nantinya - sebagai manusia hanya perlu berakhlak menghadapinya. Bahwa sebagaimana yang dikatakan al-Farabi yang penulis kutip dari jurnal yang berjudul Konsep Kebahagiaan Perspektif al-Farabi bahwa semakin manusia berakhlak semakin bahagia hidupnya - hanya dengan berakhlaklah manusia dapat menjadi bahagia (Putri, 2018: 106)

\section{Kesimpulan}

Berdasarkan pembahasan di atas dapat disimpulkan bahwa bahwa implementasi konsep thuma'ninah Ibnu Qayyim al-Jauziyah sebagai

\section{Daftar Kepustakaan}

Bagir, Haidar. 2015. Belajar Hidup dari Rumi: Serpihan-serpihan Puisi Penerang Jiwa. Bandung: Mizan.

\section{Bakker, Anton dan Achmad Charris Zubair. 1990.Metodologi}

upaya mengelola kecemasan yang terjadi pada pandemi Covid-19, yaitu; pertama, mengimplementasikan pemahamannya tentang kitab Allah Allah. Dalam hal ini, memahami ayat al-Quran yang berhubungan dengan kesabaran. Adanya kesabaran yang dimiliki sesorang pada masa pandemi Covid-19 ini menjadikan seseorang menahan diri untuk tidak berkeluh kesah dan menerima apa yang terjadi. Namun, terus berusaha menjalani kehidupan ini semaksimal dan sebaik mungkin.

Kedua, mengimplementasikan asma Allah tentang asy-Syukur. Bahwa dengan adanya rasa kesyukuran di dalam diri seorang pada masa pandemi Covid-19 ini, seseorang tersebut akan memahami bahwa ingatan tentang nikmat Allah jauh lebih besar/banyak dibandingkan apa yang dirasakan saat ini. Ketiga, mengimplementasikan pemahaman tentang ujian adalah bentuk kasih sayang Allah kepada hamba-Nya. Kesadaran bahwa apapun yang terjadi dalam hidup ini, tidak lepas dari cara Allah memberikan kebahagiaan pada manusia. Maka, ujian dalam bentuk apapun itu akan dipahami sebagai bentuk kasih sayang dari Allah.

\section{Penelitian} Filsafat. Yogyakarta: Kanisius.

Burhan, Erlina. 2020. "Coronavirus Disease 2019 (Covid 19)”. http://luk.staff.ugm.ac.id/artikel /virus/ErlinaBurhan-COVID19.pdf. Akses 25 Maret 2021. 
Departemen Agama RI. 2017. Mushaf al-Quran dan Terjemahannya. Jakarta: CV. Pustaka al-Kautsar. Cet. ke-3.

Darwis, Rizal. 2017. "Pemikiran Ibnu Qayyim al-Jauziyah terhadap Paradigma Perubahan Hukum". Jurnal Hukum dan Ekonomi Syariah. 05 (01). https://ejournal.metrouniv.ac.id/index.p hp/adzkiya/article/view/1006. Akses 26 Maret 2021.

Firdaus. 2020. "Virus Corona dalam Perspektif Sunnah". alMubarak: Jurnal Kajian alQuran dan Tafsir. 05 (01). 2020.

http://journal.iaimsinjai.ac.id/in dex.php/almubarak/article/view/292. Akses 26 Maret 2021.

Hafizullah. 2018. "Metode Penafsiran Ibnu Qayyim al-Jauziyah". Jurnal Ullunuha. 07 (01). https://ejournal.uinib.ac.id/jurna 1/index.php/ulunnuha/article/vie w/238. Akses 26 Maret 2021.

Indriya. 2020. "Konsep Tafakkur dalam al-Quran dalam Menyikapi Coronavirus Covid 19". Salam: Jurnal Sosial dan Budaya Syar-i. 07 (03). http://journal.uinjkt.ac.id/index. $\mathrm{php} / \mathrm{salam} /$ article/view/15050. Akses 26 Maret 2021.

Islami, Anggi Anggraeni dan Rifki Rosyad. 2020. "Pendidkan Anak Perspektif Sufistik dalam Pandangan Ibnu Qayyim alJauziyah". Syifa al-Qulub. 04 (02). https://journal.uinsgd.ac.id/inde x.php/syifa-alqulub/article/view/7587. Akses 27 Maret 2021.

Al-Jauziyah, Ibnu Qayyim. 1980. Madarijus Salikin: Madarij alSalikin Baina Manazil Iyyaka Na'bud wa Iyyaka Nasta'in. Libanon: Dar al-Kitab al-Arabi.

2000. Miftah Dar alSa'adat wa Manshur Wilayat al-Ilm wa al-Irada. Libanon: Dar al-Hadits.

Makmudi, dkk. 2018. "Pendidikan Jiwa Perspektif Ibn Qayyim alJauziyah". Ta'dibuna. 07 (01). http://ejournal.uikabogor.ac.id/index.php/. Akses 26 Maret 2021.

Mahfud, Choirul. 2014. "The Power of Syukur: Tafsir Kontekstual Konsep Syukur dalam alQuran”. Episteme. 09 (02). https://www.researchgate.net/p ublication/304213285. Akses 31 Maret 2021.

Maula, Wahidatun Nikmatul. 2019. "Konsep Pendidikan Anak Perspektif Ibnu Qayyim alJauziyah dalam Kitab Tuhfatul Maudud bi Ahkamil Maulud (Analisis Relevansinya dengan Pendidikan Islam Modern)". Tesis. Malang: UIN Maulanan Malik Ibrahim, 2019. http://etheses.uinmalang.ac.id/14654/. Akses 28 Maret 2021.

Muslim, Muhammad bin Abd Razak. 2019. "Konsep Lafaz Sakinah 
dan Thuma'ninah dalam alQuran". Skripsi. Aceh: UIN arRaniry. https://repository.arraniry.ac.id/id/eprint/7316/1/PD F\%20DIGABUNG\%20KESEL URUHAN\%20ISI.pdf. Akses 09 April 2021.

Na'mah, Ulin. 2015. “Ibnu Qayyim al-Jauziyah dan Pendapatnya tentang Tradisi Kalam", Universum. $09 \quad$ (01). https://jurnal.iainkediri.ac.id/in dex.php/universum/article/view 175. Akses 28 Maret 2021.

Ni’mah, Zetty Azizatun. 2018. "Menelisik Revitalisasi Pendidkan Agama Islam dalam Konsep Ibnu Qayyim alJauziyah (1292 - 1350 M)". Edudeena. $02 \quad$ (02). https://jurnal.iainkediri.ac.id/in dex.php/edudeena/article/view/ 725. Akses 27 Maret 2021.

Nurislaminingsih, Rizki. 2020. "Layanan Pengetahuan tentang Covid 19 di Lembaga Informasi”. Tik Ilmeu: Jurnal Ilmu Perpustakaan dan Informasi. $04 \quad$ (01). http://journal.iaincurup.ac.id/in dex.php/TI/article/view/1468. Akses 28 Maret 2021.

Persakmi. 2020. "Mayoritas Masyarakat Indonesia Alami Kecemasan di Masa Pandemi Covid 19". Artikel. http://persakmi.or.id/headlines/ mayoritas-masyarakatindonesia-alami-kecemasan-dimasa-pandemi-covid-19/. Akses 29 Maret 2021.
Putri, Andini Permana Kartika dan Ardi Septiawan. 2020. "Manajemen Kecemasan Masyarakat dalam Menghadapi Pandemi Covid 19". Academica: Journal of Multidisciplinary Studies. 04 (02).

http://ejournal.iainsurakarta.ac.i d/index.php/academica/article/v iew/3168. Akses 28 Maret 2021.

Putri, Endrika Widdia. 2018. "Konsep Kebahagiaan dalam Perspektif al-Farabi”. $\begin{array}{lll}\text { Thaqafiyyat. } & 19 & \text { (01). }\end{array}$ http://ejournal.uinsuka.ac.id/adab/thaqafiyyat/arti cle/view/1321. Akses 29 Marer 2021.

----------. 2019. "Zuhud Milenial dalam Perspektif Hadis". ElAfkar. $08 \quad$ (02). 2019. https://ejournal.iainbengkulu.ac .id/index.php/elafkar/article/vie w/2243. Akses 29 Maret 2021.

Riyadi, Abdul Kadir. 2016. Arkeologi Tasawuf: Melacak Jejak Pemikiran Tasawuf dari alMuhasibi hingga Tasawuf Nusantara. Bandung, Mizan Pustaka.

Supriatna, Eman. 2020. "Wabah Corona Virus Disease Covid 19 dalam Pandangan Islam". Salam: Jurnal Sosial dan Budaya Syar'i. 07 (06). http://journal.uinjkt.ac.id/index. php/salam/article/view/15247. Akses 26 Maret 2021. 
Sudarto. 2020. Metodologi Penelitian Filsafat. Jakarta: PT RajaGrafindo Persada. Cet.ke3.

Susilo, Adityo., dkk. 2020. "Coronavirus Disease 2019: Tinjauan Literatur Terkini”. Jurnal Penyakit dalam Indonesia. 07 (01). 2020. https://www.researchgate.net/p ublication/340380088. Akses 25 Maret 2021.
Yuliana. 2020 "Corona Virus Disease (Covid 19); Sebuah Tinjauan Literatu". Wellness and Healthy Magazine. $02 \quad$ (01). https://wellness.journalpress.id/ wellness/article/view/21026. Akses 25 Maret 2021.

https://covid19.go.id/peta-sebaran$\underline{\text { covid19 }}$

https://en.wikipedia.org/wiki/Templat e:COVID-19_pandemic_data 